\title{
PENGARUH TOTAL ASSET TURNOVER, DEBT TO EQUITY RATIO (DER), UKURAN PERUSAHAAN, NILAI TUKAR RUPIAH, DAN IHSG TERHADAP TERJADINYA TINGKAT UNDERPRICING SAHAM
}

\author{
Renitia*, Suripto, M. Iqbal Harori \\ Jurusan Ilmu Administrasi Bisnis, Fakultas Ilmu Sosial dan Politik, Universitas Lampung \\ *renitia53@gmail.com
}

\begin{abstract}
This study aims to determine the influence of total asset turnover, debt to equity ratio (DER), company size, rupiah exchange rate and IHSG on the occurrence of stock underpricing levels. The population used is companies that conduct IPO (Initial Public Offering) on the Indonesia Stock Exchange period 2015-2019, the population of 177 companies and samples in this study are 133 companies determined through purposive sampling. The data analysis techniques used are multiple linear regression analysis and hypothesis test with t-test and F-test. Based on the hypothetical test results showed that partial variable total asset turnover and the size of the company had a significant effect on the occurrence of stock underpricing, while other variables namely debt to equity ratio, rupiah exchange rate and IHSG were not shown to have a significant effect on the occurrence of stock underpricing. F test results showed that total asset turnover, debt to equity ratio (DER), company size, rupiah exchange rate, and JCI simultaneously had a significant effect on the level of stock underpricing.
\end{abstract}

Keywords: total asset turnover, debt to equity ratio, company size, rupiah exchange rate, underpricing

\begin{abstract}
ABSTRAK
Penelitian ini bertujuan untuk mengetahui pengaruh total asset turnover, debt to equity ratio (DER), ukuran perusahaan, nilai tukar rupiah dan IHSG terhadap terjadinya tingkat underpricing saham. Populasi yang digunakan adalah perusahaan yang melakukan IPO (Initial Public Offering) di Bursa Efek Indonesia selama tahun 2015-2019, populasi sebanyak 177 perusahaan, dan sampel dalam penelitian ini adalah 133 perusahaan yang ditentukan melalui purposive sampling. Teknik analisis data yang digunakan adalah analisis regresi linier berganda, dan pengujian hipotesis uji $\mathrm{t}$ dan uji $\mathrm{F}$. Berdasarkan hasil uji hipotesis menunjukkan bahwa secara parsial variabel total asset turnover dan ukuran perusahaan berpengaruh signifikan terhadap terjadinya underpricing saham, sedangkan variabel lain yaitu debt to equity ratio, nilai tukar rupiah, dan IHSG tidak terbukti berpengaruh signifikan terhadap terjadinya underpricing saham. Hasil uji $\mathrm{F}$ menunjukkan bahwa total asset turnover, debt to equity ratio (DER), ukuran perusahaan, nilai tukar rupiah, dan IHSG secara
\end{abstract}


simultan berpengaruh signifikan terhadap tingkat underpricing saham.

Kata kunci: total asset turnover, debt to equity ratio, ukuran perusahaan, nilai tukar rupiah, underpricing

\section{PENDAHULUAN}

Perusahaan akan selalu membutuhkan tambahan modal yang besar untuk mengembangkan bisnisnya. Banyak perusahaan yang berusaha mengembangkan usahanya dalam persaingan bisnis, salah satunya dengan beradaptasi dengan perkembangan ekonomi yang berkelanjutan dengan mengembangkan usahanya (Gunawan, 2015). Perusahaan bisa mendapatkan tambahan modal dari dalam perusahaan, maupun dari luar perusahaan (Renoldy, 2018). Biasanya perusahaan akan melakukan penjualan saham kepada publik atau biasa disebut dengan go public guna mendapatkan tambahan modal dari luar perusahaan, sehingga kemudian muncul istilah initial public offering (IPO), yakni penawaran saham secara perdana (Jogiyanto, 2010).

Pada perusahaan yang melakukan IPO, sering ditemukan kondisi yang diistilahkan sebagai underpricing. Underpricing artinya harga penutupan saham di pasar perdana lebih rendah dari harga penutupan saham dengan saham yang sama di pasar sekunder, atau terdapat selisih positif antara harga saham di pasar sekunder dengan pasar perdana (Sembiring, et al., 2018). Pada umumnya, terjadinya underpricing ini merugikan perusahaan dikarenakan tidak mendapatkan perolehan dana yang maksimum. Namun sebaliknya, fenomena underpricing ini menguntungkan bagi investor karena mendapatkan return saham. Adapun fenomena underpricing yang terjadi di Indonesia pada perusahaan yang melakukan IPO di BEI dalam periode 2015-2019 dengan jumlah sebagai berikut:

Tabel 1. Jumlah perusahaan underpricing periode 2015-2019

\begin{tabular}{|c|c|c|c|}
\hline Tahun & $\begin{array}{c}\text { Perusahaan yang } \\
\text { mendaftarkan IPO }\end{array}$ & Underpricing & Tidak Underpricing \\
\hline 2015 & 18 & 13 & 5 \\
\hline 2016 & 15 & 10 & 5 \\
\hline 2017 & 35 & 33 & 2 \\
\hline 2018 & 54 & 48 & 6 \\
\hline 2019 & 55 & 51 & 4 \\
\hline Total & $\mathbf{1 7 7}$ & $\mathbf{1 5 5}$ & $\mathbf{2 2}$ \\
\hline
\end{tabular}

Berdasarkan tabel 1 diketahui tingkat underpricing pada perusahaan yang melakukan penawaran saham perdana (IPO) dari tahun 2015 sampai 2019 sangatlah tinggi. Selama 5 tahun terakhir dari total 177 yang melakukan IPO, terdapat 155 perusahaan mengalami underpricing, dan 22 perusahaan tidak mengalami underpricing. Hal ini menunjukkan bahwa salah satu tahapan tersulit dalam mekanisme proses IPO adalah menentukan harga saham perdana perusahaan berdasarkan harga pasarnya (Haska, 2017).

Penelitian telah banyak dilakukan terhadap faktor-faktor yang mempengaruhi tingkat 
underpricing pada perusahaan yang melakukan IPO. Namun karena temuannya tidak selalu konsisten, maka penelitian tersebut tetap dianggap menarik. Dalam penelitian ini, dikembangkan 5 faktor yang mempengaruhi tingkat underpricing pada perusahaan yang melakukan IPO, yaitu total asset turnover, debt to equity ratio (DER), ukuran perusahaan, nilai tukar rupiah dan IHSG sebagai variabel independen.

Total asset turnover merupakan salah satu faktor yang dapat mempengaruhi tingkat underpricing saham. TATO (Total Asset Turnover) merupakan rasio aktivitas yang mencerminkan perusahaan dalam mengelola asetnya. Semakin tinggi perputaran aset perusahaan, maka semakin baik tingkat efesiensi perusahaan dalam mengelola asetnya. Sehingga dapat dijelaskan bahwa semakin tinggi nilai TATO, maka akan semakin rendah tingkat underpricing dalam perusahaan.

Debt to Equity Ratio (DER) merupakan rasio yang digunakan untuk membandingkan rasio hutang perusahaan terhadap total modal. Penelitian yang dilakukan Aini (2013) menyatakan bahwa debt to equity ratio (DER) berpengaruh positif dan signifikan terhadap terjadinya underpricing. Kondisi ini terjadi karena DER menunjukkan keberhasilan manajemen dalam memenuhi kewajiban jangka panjangnya. Semakin tinggi DER perusahaan, semakin tinggi tingkat underpricing pada perusahaannya.

Dampak depresiasi nilai tukar rupiah terhadap mata uang asing menjadi sinyal yang kurang baik bagi pasar saham, karena membuat pasar menjadi tidak menarik di mata para investor saham. Artinya, jika nilai tukar rupiah naik maka permintaan saham dipasar sekunder akan menurun, dan harga di pasar perdana akan sangat rendah atau atau underpriced. Penelitian yang dilakukan Imawati (2017) dan Fitriani (2019) menyatakan bahwa nilai tukar rupiah berpengaruh signifikan terhadap underpricing.

Kondisi pasar ialah salah satu faktor luar yang dapat mempengaruhi terjadinya underpricing. Penelitian yang dilakukan Sukirman et al (2011) menyatakan bahwa kondisi pasar yang diproyekskan dengan IHSG berpengaruh terhadap underpricing. Hal ini berarti jika harga saham dalam kondisi baik, maka emiten dan penjamin emisi akan memiliki kepercayaan untuk menetapkan harga penawaran perdana yang lebih tinggi, dan meminimalkan underpricing. Oleh karena itu, dalam kondisi pasar yang stabil, peluang terjadinya fenomena underpricing akan berkurang.

Berdasarkan uraian yang telah dipaparkan pada latar belakang tersebut, maka hipotesis dalam penelitian ini ialah sebagai berikut:

$\mathrm{H}_{1} \quad$ : Total Asset Turnover berpengaruh signifikan terhadap underpricing

$\mathrm{H}_{2}$ : Debt to equity ratio (DER) berpengaruh signifikan terhadap Underpricing

$\mathrm{H}_{3}$ : Ukuran perusahaan berpengaruh signifikan terhadap underpricing

$H_{4} \quad$ : Nilai Tukar Rupiah berpengaruh signifikan terhadap underpricing

$\mathrm{H}_{5}$ : IHSG berpengaruh signifikan terhadap underpricing

$\mathrm{H}_{6}$ : Total Asset Turnover, debt to equity ratio (DER), ukuran perusahaan, nilai tukar rupiah (kurs), dan IHSG secara simultan berpengaruh terhadap underpricing saham

\section{METODE PENELITIAN}

Jenis penelitian yang digunakan dalam penelitian ini yaitu penelitian kuantitatif. Populasi dalam penelitian ini adalah seluruh perusahaan yang melakukan penawaran umum perdana (IPO) di Bursa Efek Indonesia selama tahun 2015-2019 yang mengalami 
underpricing. Pengambilan sampel dalam penelitian ini menggunakan non probability sampling dengan teknik sampling yang digunakan yaitu purposive sampling, teknik pengambilan sampel dengan karakteristik khusus yang sesuai dengan tujuan penelitian, sehingga diharapkan dapat menyelesaikan masalah penelitian (Sugiyono 2017). Sampel penelitian ini berjumlah 133 perusahaan yang memenuhi kriteria. Teknik analisis data yang digunakan dalam penelitian ini menggunakan analisis regresi linier berganda dengan bantuan SPSS 22.

\section{HASIL PENELITIAN}

\section{Analisis Statistik Deskriptif}

Tabel 2 Hasil Uji Statistik Deskriptif

\begin{tabular}{|l|l|l|l|l|l|}
\hline Descriptive Statistics & $\mathrm{N}$ & Minimum & Maximum & Mean & $\begin{array}{l}\text { Std. } \\
\text { Deviation }\end{array}$ \\
\hline UNDERPRICING & 133 & .00500 & 92800 & .4539474 & .24093940 \\
\hline TATO & 133 & .00056 & 3.48244 & .9409848 & .74792160 \\
\hline DER & 133 & 00221 & 4.03256 & 9002960 & 78037035 \\
\hline Ukuran Perusahaan & 133 & 22.44786 & 30.81403 & 26.8804604 & $\begin{array}{l}1.5321808 \\
3\end{array}$ \\
\hline Nilai Tukar Rupiah & 133 & 13.99250 & 15233.00000 & 13864.5976880 & $\begin{array}{l}1324.1243 \\
8761\end{array}$ \\
\hline IHSG & 133 & -472.56689 & 598.89209 & 4.5231876 & $\begin{array}{l}240.99427 \\
150\end{array}$ \\
\hline Valid N (listwise) & 133 & & & & \\
\hline
\end{tabular}

Berdasarkan tabel 2, dapat diketahui hasil analisis deskriptif adalah sebagai berikut:

1. Tingkat underpricing perusahaan terendah pada tahun 2015-2019 adalah sebesar 0,00500 atau 0,5\%, yaitu Perusahaan Sarimelati Kencana Tbk. Tingkat underpricing tertinggi terjadi di tahun 2019 sebesar 0,92800 atau 92,80\%, yaitu PT Kencana Energi Lestari Tbk. Sedangkan rata-rata emiten yang mengalami underpricing di Bursa Efek Indonesia sebesar 0,4539474 atau $45,9474 \%$. Hal tersebut dapat terlihat bahwa perusahaan yang dijadikan sampel menetapkan harga saham penawaran perdana terlalu rendah dibandingkan harga yang dijual di pasar sekunder. Standar deviasi pada tingkat underpricing menyatakan bahwa ukuran penyebarannya adalah sebesar 0,24093940 dari 133 perusahaan.

2. Total asset turnover terendah yakni 0,00056, dimiliki oleh Perusahaan Ayana Land International Tbk pada tahun 2017. Sedangkan nilai TATO tertinggi sebesar 3,48244 dimiliki oleh PT Hensel Davest Indonesia, Tbk. pada tahun 2019. Mean dalam penelitian ini sebesar 0,9409848, yang artinya rata-rata dari sampel perusahaan dalam penelitian ini memiliki rasio total asset turover sebesar 94,09\% dari total aset perusahaan. Standar deviasi pada nilai TATO sebesar 0,74792160.

3. Debt to equity ratio terendah yakni 0,00221, dimiliki oleh PT Fuji Finance Indonesia, Tbk. pada tahun 2019. Nilai debt to equity ratio tertinggi sebesar 4,03256, dimiliki oleh PT Arkha Jayanti Persada, Tbk. pada tahun 2019. Variabel DER dari 133 sampel perusahaan diperoleh nilai rata-rata sebesar 0,9002960. Standar deviasi sebesar 
0,78037035, menunjukkan bahwa ukuran penyebaran dari debt to equity ratio adalah sebesar 0,78037035 dari 133 kasus yang terjadi.

4. Ukuran perusahaan terendah dimiliki oleh Perusahaan Yelooo Integra Datanet, Tbk. sebesar 22,44786 pada tahun 2018. Perusahaan yang memiliki ukuran perusahaan tertinggi sebesar 30,81403 adalah Bintang Oto Global, Tbk. pada tahun 2016. Variabel ukuran perusahaan dari 133 sampel perusahaan diperoleh nilai rata-rata sebesar 26,8804604, dengan standar deviasi 1,53218083. Standar deviasi menunjukkan ukuran penyebaran dari ukuran perusahaan adalah sebesar 1,53218083 dari 133 kasus yang terjadi.

5. Nilai tukar rupiah terendah sebesar 12926 pada saat IPO, sedangkan nilai tertinggi sebesar 139925. Data menunjukkan dari 133 perusahaan sampel diperoleh nilai ratarata sebesar 14916,56, dan standar deviasi sebesar 10934,94 yang berarti ukuran penyebaran adalah sebesar 10934,94 dari 133 perusahaan.

6. Hasil statistik variabel IHSG dalam penelitian ini dari 133 sampel perusahaan diperoleh nilai rata-rata sebesar 4,5231876, dengan standar deviasi sebesar 240,99427150. Standar deviasi menunjukkan bahwa ukuran penyebaran dari IHSG adalah sebesar 240,99427150 dari 133 kasus yang terjadi, atau terjadi penyimpangan yang cukup tinggi dari nilai rata-ratanya, karena standar deviasi lebih dari nilai ratarata. Nilai IHSG tertinggi sebesar 598.89209, sedangkan nilai IHSG terendah sebesar $-472,56689$.

\section{Hasil Uji Asumsi Klasik}

\section{Uji Normalitas}

Uji normalitas dalam penelitian ini digunakan untuk menguji variabel pengganggu atau residual distribusi normal atau tidak dalam model regresi. Model regresi yang baik ialah memiliki distribusi data normal atau data penelitian mendekati normal. Penelitian ini menggunakan analisis grafik P-P Plot untuk mengetahui normalitas data. Berikut ini adalah hasil uji normalitas data:

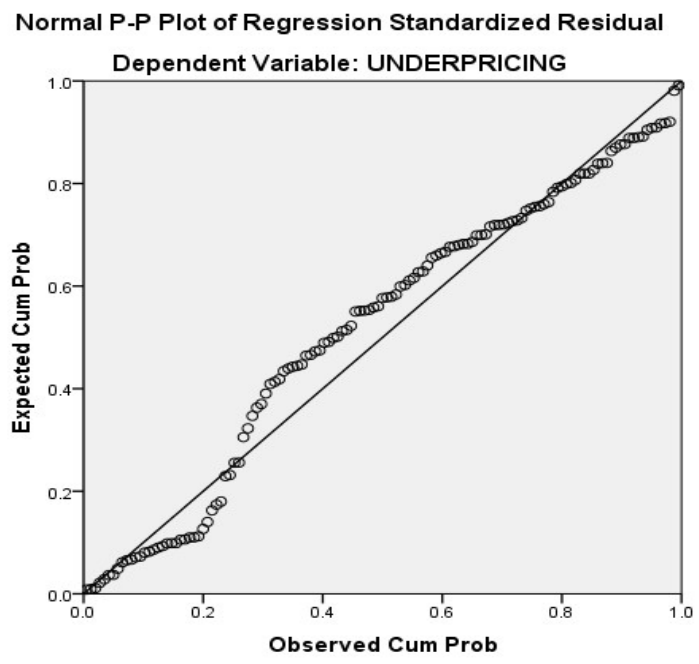

Gambar 1. Hasil Uji Normalitas

Berdasarkan gambar 1. diketahui bahwa P-Plot yang menunjukkan pola berdistribusi 
normal, dimana titik-titik mendekati garis diagonal dan mengikuti arah garis diagonal. Hal tersebut berarti bahwa semua variabel-variabel dalam model regresi dapat dikatakan terdistribusi normal. Hal ini bisa disimpulkan bahwa model regresi telah memenuhi asumsi uji normalitas.

\section{Uji Multikolinearitas}

Tabel 3 Hasil Uji Multikolinearitas

\begin{tabular}{|c|c|c|c|}
\hline \multicolumn{4}{|c|}{ Coefficients $^{a}$} \\
\hline \multirow{2}{*}{\multicolumn{2}{|c|}{ Model }} & \multicolumn{2}{|c|}{ Collinearity Statistics } \\
\hline & & Tolerance & VIF \\
\hline \multirow[t]{6}{*}{1} & (Constant) & & \\
\hline & TATO & .903 & 1.107 \\
\hline & DER & .988 & 1.012 \\
\hline & Ukuran Perusahaan & .858 & 1.165 \\
\hline & Nilai Tukar Rupiah & .967 & 1.034 \\
\hline & IHSG & .962 & 1.039 \\
\hline
\end{tabular}

Berdasarkan tabel 3 dapat diketahui bahwa nilai tolerane variabel TATO sebesar 0,903 $\geq 0,1$ dan nilai VIF $1,107 \leq 10$. Variabel debt to equity ratio (DER) memiliki nilai tolerance 0,988 $\geq 0,1$ dan nilai VIF $1,012 \leq 10$. Variabel ukuran perusahaan memiliki nilai tolerance $0,858 \geq$ 0,1 , dan nilai VIF 1,165 $\leq 10$. Variabel nilai tukar rupiah memiliki nilai tolerance $0,967 \geq 0,1$ dan nilai VIF $1,034 \leq 10$. Variabel IHSG memiliki nilai tolerance $0,962 \geq 0,1$, dan nilai VIF $1,039 \leq 10$. Berdasarkan hasil tersebut dapat disimpulkan model regresi telah memenuhi asumsi multikolinearitas, dikarenakan nilai tolerance $\geq 0,1$ dan nilai Variance Inflation Factor $(\mathrm{VIF}) \leq 10$.

\section{Uji Heteroskedastisitas}

Pada penelitian ini dilakukan melalui pengamatan grafik scatterplot yang merupakan cara untuk mendeteksi ada atau tidaknya heteroskedastisitas dalam penelitian ini. Berikut ini adalah hasil uji heteroskedastisitas yang telah dilakukan antara lain:

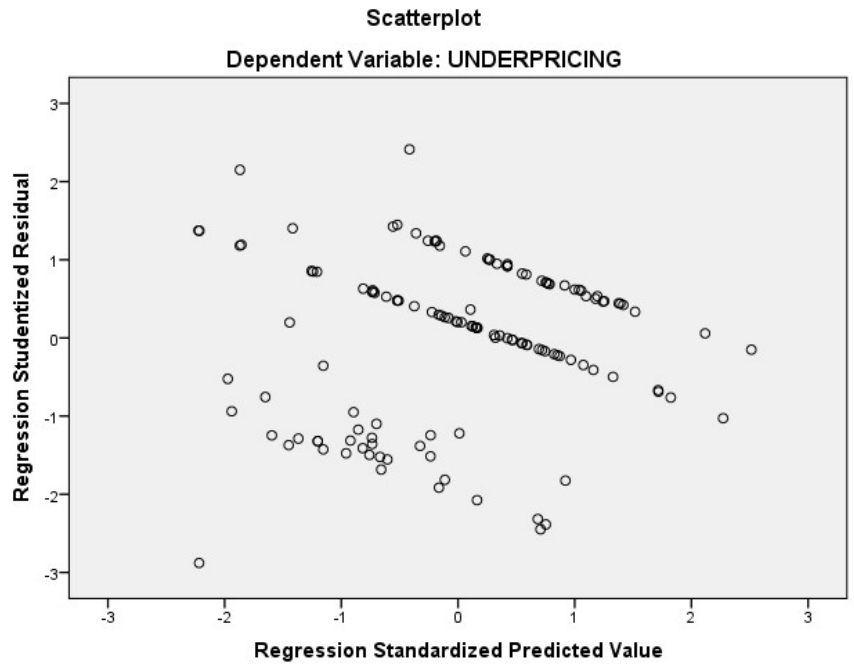

Gambar 2. Hasil Uji Heteroskedastisitas 
Berdasarkan gambar 2 dapat disimpulkan bahwa hasil dalam penelitian ini tidak ada pola yang jelas, serta titik-titiknya menyebar di atas dan di bawah angka 0 pada sumbu Y. Berdasarkan gambar di atas, dapat disimpulkan bahwa dalam penelitian ini tidak terdapat adanya masalah heteroskedastisitas dan model regresi telah memenuhi asumsi heteroskedastisitas.

\section{Uji Autokorelasi}

Pada penelitian ini cara agar bisa mengetahui ada atau tidak adanya autokorelasi menggunakan uji Run Test. Berikut ini adalah hasil uji Run Test dari model regresi:

Tabel 4. Hasil Uji Run Test

\begin{tabular}{|c|c|}
\hline \multicolumn{2}{|l|}{ Runs Test } \\
\hline & $\begin{array}{l}\text { Unstandardized } \\
\text { Residual }\end{array}$ \\
\hline Test Value $^{a}$ & .04230 \\
\hline Cases $<$ Test Value & 66 \\
\hline Cases $>=$ Test Value & 67 \\
\hline Total Cases & 133 \\
\hline Number of Runs & 66 \\
\hline Z & -.260 \\
\hline Asymp. Sig. (2-tailed) & .794 \\
\hline
\end{tabular}

Pada tabel 4, diperoleh hasil Asymp. Sig. sebesar 0,794, yang berarti bahwa tingkat signifikansi lebih dari 0,05, sehingga dapat disimpulkan bahwa dalam model regresi tidak terjadi masalah autokorelasi.

Uji Regresi Linear Berganda

Tabel 5. Hasil Regresi Linear Berganda

\begin{tabular}{|c|c|c|c|c|c|}
\hline \multicolumn{6}{|l|}{ Coefficients ${ }^{a}$} \\
\hline \multirow[b]{2}{*}{ Model } & \multicolumn{2}{|c|}{$\begin{array}{l}\text { Unstandardized } \\
\text { Coefficients }\end{array}$} & \multirow{2}{*}{\begin{tabular}{|l} 
Standardized \\
Coefficients \\
Beta \\
\end{tabular}} & \multirow[b]{2}{*}{$\mathrm{T}$} & \multirow[b]{2}{*}{ Sig. } \\
\hline & $\mathrm{B}$ & Std. Error & & & \\
\hline \begin{tabular}{|l|l|}
1 & (Constant) \\
\end{tabular} & 2.409 & .365 & & 6.607 & .000 \\
\hline TATO & -.096 & .027 & -.299 & -3.599 & .000 \\
\hline DER & .026 & .024 & .084 & 1.063 & .290 \\
\hline Ukuran Perusahaan & -.070 & .013 & -.445 & -5.231 & .000 \\
\hline Nilai Tukar Rupiah & $-3.543 \mathrm{E}-7$ & .000 & -.016 & -.200 & .841 \\
\hline IHSG & $5.412 \mathrm{E}-5$ & .000 & .054 & .673 & .502 \\
\hline
\end{tabular}

Berdasarkan tabel 5, model regresi linear berganda yang digunakan dalam penelitian ini adalah sebagai berikut.

$$
Y=2,409-0,096\left(\mathrm{X}_{1}\right)+0,026\left(\mathrm{X}_{2}\right)-0,070\left(\mathrm{X}_{3}\right)-3,\left(\mathrm{X}_{4}\right)+5,412\left(\mathrm{X}_{5}\right)+\mathrm{e}
$$

Keterangan: $\mathrm{Y}=$ underpricing pada perusahaan; $\mathrm{X}_{1}=$ total asset turnover; $\mathrm{X}_{2}=$ debt to equity ratio

(DER); $X_{3}=$ ukuran perusahaan; $X_{4}=$ nilai tukar rupiah; $X_{5}=$ IHSG

1. Nilai konstanta sebesar 2,409 , artinya underpricing pada perusahaan akan bernilai 
2,409, jika total asset turnover, debt to equity ratio, ukuran perusahaan, nilai tukar rupiah dan IHSG bernilai 0 .

2. Nilai koefisien total asset turnover $\left(X_{1}\right)$ menunjukkan nilai negatif sebesar $-0,096$, yang artinya setiap total asset turnover $\left(\mathrm{X}_{1}\right)$ mengalami peningkatan sebesar 1 , maka akan berdampak pada penurunan tingkat underpricing $(\mathrm{Y})$ sebesar 0,096, dengan asumsi koefisien regresi variabel lain adalah nol.

3. Nilai koefisien debt to equity ratio $\left(\mathrm{X}_{2}\right)$ menunjukkan nilai positif sebesar 0,026 , yang artinya setiap terjadi peningkatan jumlah debt to equity ratio $\left(\mathrm{X}_{2}\right)$ sebesar 1 , maka akan berdampak pada peningkatan tingkat underpricing $(\mathrm{Y})$ sebesar 0,026 , dengan asumsi koefisien regresi variabel lain adalah nol.

4. Nilai koefisien ukuran perusahaan $\left(X_{3}\right)$ menunjukkan nilai negatif sebesar $-0,070$, yang artinya setiap ukuran perusahaan $\left(\mathrm{X}_{3}\right)$ bernilai sebesar 1, maka akan berdampak pada penurunan tingkat underpricing $(\mathrm{Y})$ sebesar 0,070, dengan asumsi koefisien regresi variabel lain adalah nol.

5. Nilai koefisiensi nilai tukar rupiah $\left(X_{4}\right)$ menunjukkan nilai negatif sebesar $-3,543$, artinya jika nilai tukar rupiah $\left(\mathrm{X}_{4}\right)$ meningkat 1 rupiah sedangkan variabel lain tetap, maka akan menyebabkan penurunan tingkat underpricing $(\mathrm{Y})$ sebesar 3,543, dengan asumsi koefisien regresi variabel lain adalah nol.

6. Nilai koefisiensi IHSG $\left(X_{5}\right)$ menunjukkan nilai positif sebesar 5,412, yang artinya jika setiap terjadi peningkatan nilai IHSG $\left(X_{5}\right)$ sebesar 1 akan berdampak pada peningkatan tingkat underpricing $(\mathrm{Y})$ sebesar 5,412, dengan asumsi koefisien regresi variabel lain adalah nol.

\section{Uji Hipotesis}

Uji Signifikasi Parameter Individual (Uji Statistik t)

Uji signifikasi parameter individual dalam penelitian ini digunakan untuk mengetahui pengaruh masing-masing variabel independen terhadap variabel dependen (Ghozali, 2016). Berikut ini merupakan penjelasan dari hasil uji signifikansi parameter individual (uji statistik $\mathrm{t}$ ) pada tabel 5 sebagai berikut:

1) Variabel TATO mempunyai nilai koefisien regresi sebesar $-0,096$, bernilai negatif (-) dengan signifikansi sebesar 0,000, dimana nilai tersebut lebih kecil dari 0,005. Hal ini menunjukkan bahwa variabel TATO berpengaruh signifikan dengan arah hubungan negatif terhadap tingkat underpricing. Dengan demikian, hipotesis pertama yaitu TATO berpengaruh signifikan terhadap underpricing terdukung.

2) Variabel DER mempunyai nilai koefisien regresi sebesar 0,026 , bernilai positif $(+)$ dengan signifikansi sebesar 0,290, dimana nilai tersebut lebih besar dari 0,005. Hal ini menunjukkan bahwa variabel DER tidak berpengaruh signifikan terhadap tingkat underpricing saham. Dengan demikian, hipotesis kedua yaitu DER berpengaruh signifikan terhadap underpricing tidak terdukung.

3) Variabel ukuran perusahaan mempunyai nilai koefisien regresi sebesar $-0,070$, bernilai negatif (-) dengan signifikansi sebesar 0,000, dimana nilai tersebut lebih kecil dari 0,005. Hal ini menunjukkan bahwa variabel ukuran perusahaan berpengaruh signifikan dengan arah hubungan negatif terhadap tingkat underpricing. Dengan demikian, hipotesis ketiga yaitu ukuran perusahaan berpengaruh signifikan terhadap underpricing terdukung.

4) Variabel nilai tukar rupiah mempunyai nilai koefisien regresi sebesar -3,543, bernilai 
negatif (-) dengan signifikansi sebesar 0,841, dimana nilai tersebut lebih besar dari 0,005. Hal ini menunjukkan bahwa variabel nilai tukar rupiah tidak berpengaruh signifikan terhadap tingkat underpricing saham. Dengan demikian, hipotesis keempat yaitu nilai tukar rupiah berpengaruh signifikan terhadap underpricing tidak terdukung.

5) Variabel IHSG mempunyai nilai koefisien regresi sebesar 5,412, bernilai positif $(+)$ dengan signifikansi sebesar 0,502, dimana nilai tersebut lebih besar dari 0,005. Hal ini menunjukkan bahwa variabel IHSG tidak berpengaruh signifikan terhadap tingkat underpricing saham. Dengan demikian, hipotesis kelima yaitu IHSG berpengaruh signifikan terhadap underpricing tidak terdukung.

Uji Signifikansi Simultan (Uji Statistik F)

Tabel 6. Hasil Signifikansi Simultan (Uji Statistik F) Model Regresi

\begin{tabular}{|c|c|c|c|c|c|c|}
\hline \multicolumn{7}{|c|}{ ANOVA $^{\mathrm{a}}$} \\
\hline \multicolumn{2}{|c|}{ Model } & $\begin{array}{l}\text { Sum } \\
\text { Squares }\end{array}$ & Df & Mean Square & $F$ & Sig. \\
\hline \multirow{3}{*}{1} & Regression & 1.608 & 5 & .322 & 6.746 & $.000^{\circ}$ \\
\hline & Residual & 6.055 & 127 & .048 & & \\
\hline & Total & 7.663 & 132 & & & \\
\hline
\end{tabular}

Berdasarkan tabel 6 diketahui bahwa model regresi dalam penelitian ini memiliki nilai F sebesar 6,746, dan tingkat signifikansi 0,000. Hasil tersebut menunjukkan bahwa nilai signifikansi $\mathrm{F}<0,05$, yang berarti bahwa model regresi bersifat fit dan layak untuk dilakukan penelitian selanjutnya, atau dapat dikatakan bahwa variabel total asset turnover, debt to equity ratio, ukuran perusahaan, nilai tukar rupiah dan IHSG secara simultan berpengaruh terhadap tingkat underpricing.

\section{Uji Koefisien Determinasi (R Square)}

Pengujian koefisien determinasi $\mathrm{R}^{2}$ dalam penelitian ini dilakukan untuk mengukur seberapa besar pengaruh variabel independen secara bersama-sama menjelaskan perubahan yang terjadi pada variabel dependen. Hasil pengujian diperoleh sebagai berikut:

Tabel 7. Hasil Koefisien Determinasi (R Square)

\begin{tabular}{|l|l|l|l|}
\hline \multicolumn{4}{|l|}{ Model Summary } \\
\hline Model & R & R Square & Adjusted R Square \\
\hline 1 & $.458^{\mathrm{a}}$ & .210 & .179 \\
\hline
\end{tabular}

Berdasarkan tabel 7 model regresi menunjukkan bahwa koefisien determinasi memiliki nilai 0,179 atau $17,9 \%$. Hasil penelitian menunjukkan bahwa kemampuan variabel independen yaitu total asset turnover, debt to equity ratio, ukuran perusahaan, nilai tukar rupiah, dan IHSG dalam menjelaskan variabel dependen yaitu underpricing saham sebesar $17,9 \%$ sedangkan sisanya, sebesar $82,1 \%$ dipengaruhi oleh variabel lain yang tidak dapat dijelaskan oleh variabel independen dalam penelitian ini. 


\section{PEMBAHASAN}

\section{Pengaruh total asset turnover terhadap underpricing}

Berdasarkan hasil pengujian hipotesis yang telah dilakukan, dapat dilihat bahwa nilai standar koefisien total asset turnover yaitu sebesar -0,096, dan nilai signifikansi kurang dari 0,05 yaitu sebesar 0,000, menunjukkan bahwa variabel total asset turnover berpengaruh signifikan, dengan arah hubungan negatif terhadap underpricing. Variabel total asset turnover dalam penelitian ini diukur dengan penjualan dibagi dengan total asset.

Total asset turnover ialah rasio yang menggambarkan kemampuan perusahaan dalam mengelola aset yang dimilikinya. Tingginya nilai TATO akan mencerminkan semakin baik perusahaan dalam pengelolaan aset perusahaan tersebut. Berdasarkan hasil dari penelitian ini, rata-rata perusahaan dapat mengelola asetnya sebesar 94,09\%. Perusahaan yang memiliki tingkat efesien yang baik dalam mengelola asetnya akan memberikan signal yang positif bagi investor. Efesiensi pengelolaan aset secara tidak langsung akan berdampak pada peningkatan laba perusahaan. Menurut Barus dan Leliani (2013), perusahaan yang efektif dalam penggunaan aktivanya demi mendapatkan total penjualan yang tinggi, maka perusahaan tersebut akan mampu menghasilkan keuntungan yang tinggi juga. Selain itu, nilai TATO yang tinggi mempermudah perusahaan dalam penetapan harga penawaran saham saat IPO, sehingga perusahaan akan berani menetapkan harga yang tinggi dan akan meminimalisir terjadinya underpricing.

Hasil yang diperoleh dalam penelitian ini dapat mendukung hasil penelitian yang dilakukan oleh Maulidya (2016) dan Aridhonda (2013). Hasil penelitiannya menyebutkan bahwa variabel total asset turnover berpengaruh negatif dan signifikan terhadap tingkat underpricing. Akan tetapi, hasil penelitian ini tidak bisa mendukung penelitian yang telah dilakukan oleh Renoldy (2018) dan Yuliana (2013) yang menemukan bahwa total asset turnover tidak berpengaruh terhadap tingkat underpricing.

\section{Pengaruh debt to equity ratio (DER) terhadap underpricing}

Berdasarkan hasil pengujian hipotesis yang dilakukan, dapat dilihat bahwa nilai standar koefisien debt to equity ratio (DER) yaitu sebesar 0,026, dan nilai signifikansi lebih besar dari 0,05 yaitu sebesar 0,290, memperlihatkan bahwa variabel debt to equity ratio berpengaruh tidak signifikan, dengan arah hubungan positif terhadap underpricing. Debt to equity ratio dalam penelitian ini diukur dengan membandingkan jumlah total hutang dengan total modal.

Debt to Equity Ratio (DER) menunjukkan kemampuan perusahaan untuk memenuhi kewajiban jangka panjang dan jangka pendek dengan modal yang dimilikinya. Investor menggunakan rasio ini untuk menilai harga saham suatu perusahaan. Menurut teori signal, perusahaan yang memiliki tingkat DER yang tinggi akan menyampaikan signal yang negatif bagi investor untuk menghindari saham perusahaan dengan tingkat DER yang tinggi. Hal tersebut dikarenakan DER yang tinggi mengindikasikan perusahaan tersebut sulit memenuhi kewajiban jangka panjang maupun jangka pendeknya, sehingga akan menyebabkan terjadinya underpricing.

Hasil penelitian ini, rasio DER tidak berpengaruh signifikan terhadap tingkat underpricing saham. Kondisi tersebut dikarenakan DER yang tinggi akan berdampak pada 
besarnya resiko yang akan dihadapi oleh para investor. Berdasarkan tabel 2 diketahui bahwa terdapat perusahaan yang memiliki nilai DER tinggi sebesar 4,03256, atau dengan kata lain hutang perusahaan tersebut 4 kali dari modal yang dimilikinya. Nilai DER tersebut mencerminkan resiko yang akan dihadapi oleh investor.

Menurut trade off theory yang dikemukakan oleh Modigliani-Miller (1963) menjelaskan bahwa titik awal tinjauan keputusan struktur modal perusahaan adalah pada rasio target hutang, dimana perlindungan pajak terhadap hutang dimaksimalkan, dan biaya kepailitan yang berkaitan dengan hutang diminimalkan. Menurut Hadianto (2010), Penggunaan hutang memang akan bisa menghemat pembayaran pajak perusahaan, akan tetapi pada sisi yang lain, penggunaan hutang yang tinggi juga bisa menimbulkan kebangkrutan dan biaya agensi. Keputusan sebuah perusahaan untuk menggunakan hutang yang semakin besar akan dapat menyebabkan perusahaan tersebut kesulitan keuangan atau kebangkrutan (Wikartika dan Fitriyah, 2018). Sehingga, investor akan menghindari perusahaan yang memiliki DER yang tinggi. Penelitian ini selaras dengan penelitian yang dilakukan oleh Gunawan (2015) bahwa debt to equity ratio (DER) tidak berpengaruh signifikan terhadap tingkat underpricing saham.

\section{Pengaruh ukuran perusahaan terhadap underpricing}

Berdasarkan hasil pengujian hipotesis yang telah dilakukan, dapat dilihat bahwa nilai standar koefisien ukuran perusahaan yaitu sebesar -0,070, dengan nilai signifikansi sebesar $<0,05$ yaitu sebesar 0,000, menunjukkan bahwa variabel ukuran perusahaan berpengaruh signifikan dengan arah hubungan negatif terhadap underpricing. Ukuran perusahaan dalam penelitian ini diukur dengan logaritma natural dengan cara mentransformasikan total aktiva tersebut dalam logaritma natural.

Kencenderungan yang dimiliki investor biasanya akan menginvestasikan modalnya pada perusahaan yang mempunyai skala perusahaan yang lebih besar daripada perusahaan yang memiliki skala yang lebih kecil, karena tingkat ketidakpastian atas perusahaan dapat dilihat dari ukuran perusahaan. Ketika membaca prospektus, serta menggunakan total aktiva untuk menganalisis ukuran perusahaan, akan membuat penilaian bahwa total aktiva bisa dipergunakan untuk meningkatkan penghasilan perusahaan, dan perusahaan akan memiliki kemampuan untuk memenuhi kewajibannya, sehingga resiko ketidakpastian di masa datang bisa diperkecil, maka hal tersebut dapat mengurangi tingkat keraguan investor dalam melakukan investasi (Pahlevi, 2014). Dengan demikian, perusahaan ketika melakukan IPO, dapat menawarkan harga perdana yang relatif tinggi.

Berdasarkan hasil penelitian ini, rata-rata perusahaan mempunyai ukuran perusahaan yang besar dengan mempunyai total aset sebesar 26,8804604. Perusahaan yang mempunyai ukuran yang besar akan dapat memberikan sinyal positif bagi para investor untuk membeli saham perusahaan tersebut, sehingga emiten dan underwriter cenderung akan memutuskan penetapan harga penawaran perdana relatif lebih tinggi di atas harga sewajarnya (Yuniarti dan Syarifudin, 2020). Harga penawaran perdana atau IPO saat perusahaan melakukan go public akan mempengaruhi tingkat terjadinya underpricing, karena tingginya harga penawaran perdana yang telah ditetapkan bisa menurunkan tingkat underpricing saham. Hasil penelitian ini juga sesuai dengan hasil penelitian yang dilakukan oleh Mayasari, et al. 
(2018) yang menemukan bahwa ukuran perusahaan memiliki pengaruh negatif dan signifikan terhadap tingkat underpricing.

\section{Pengaruh nilai tukar rupiah terhadap underpricing}

Berdasarkan hasil uji hipotesis yang dilakukan, dapat dilihat bahwa nilai standar koefisien nilai tukar rupiah yaitu sebesar -3,543, dengan nilai signifikansi lebih besar dari 0,05 yaitu sebesar 0,841, menunjukkan bahwa variabel nilai tukar rupiah berpengaruh tidak signifikan dengan arah hubungan negatif terhadap underpricing. Nilai tukar yang digunakan dalam penelitian ini yaitu nilai tengah dari kurs jual dan kurs beli mata uang Rupiah terhadap US Dollar.

Hasil dari penelitian ini menyatakan bahwa perubahan nilai tukar rupiah tidak memiliki dampak terhadap harga penawaran saham di saat IPO. Peneliti menilai hal tersebut terjadi dikarenakan perubahan nilai tukar rupiah memiliki dampak yang berbedabeda untuk setiap emiten yang akan melakukan IPO. Hal tersebut terkait dengan kegiatan operasi penjualan perusahaan yang ada beberapa perusahaan mengandalkan impor, dan ada sebagian lagi perusahaan yang mengandalkan pada kegiatan ekspor. Biasanya investor jangka panjang mempunyai anggapan bahwa dampak fluktuasi nilai tukar hanya akan berlangsung sementara, atau dengan kata lain tidak akan berlangsung lama, sehingga tidak akan berpengaruh terhadap harga penawaran di saat IPO. Investor tidak menggunakan indikator perubahan nilai tukar rupiah untuk mengambil keputusan dalam berinvestasi di pasar modal.

Hasil penelitian ini mendukung oleh penelitian yang dilakukan oleh Rachmadhanto \& Raharja (2014). Hasil penelitiannya menyatakan bahwa nilai tukar rupiah tidak mempunyai pengaruh yang signifikan terhadap tingkat underpricing. Namun, hasil dari penelitian ini tidak bisa mendukung penelitian yang dilakukan oleh Imawati (2017) dan Fitriani (2019), yang mengemukakan bahwa nilai tukar rupiah memiliki pengaruh yang signifikan terhadap tingkat underpricing.

\section{Pengaruh IHSG terhadap underpricing}

Berdasarkan hasil uji hipotesis yang dilakukan, dapat dilihat bahwa nilai standar koefisien IHSG yaitu sebesar 5,412, dengan nilai signifikansi lebih besar dari 0,05 yaitu sebesar 0,502, menunjukkan bahwa variabel IHSG berpengaruh tidak signifikan dengan arah hubungan positif terhadap underpricing. Perhitungan IHSG dalam penelitian ini menggunakan selisih indeks harga saham gabungan pada masa satu bulan sebelum saham perusahaan listing dikurangi dengan indeks harga saham gabungan hari pertama perusahaan listing di pasar modal.

IHSG biasanya digunakan sebagai tolak ukur dalam melihat kondisi pasar. Kebanyakan harga saham perusahaan biasanya akan bergerak secara acak bergantung pada informasi baru yang diterima (Samsul, 2006). Jika ada informasi yang diterima bersifat kabar baik (good news), maka harga saham akan cenderung mengalami peningkatan, dan pasar dalam kondisi baik atau stabil, begitupun sebaliknya.

Hal tersebut dimaksudkan bahwa jika kondisi pasar dalam keadaan baik, maka emiten dan penjamin emisi atau underwriter akan mempunyai keyakinan untuk menetapkan harga 
penawaran perdana yang lebih tinggi saat melakukan IPO, dan akan memperkecil terjadinya tingkat underpricing. Sehingga, pada kondisi pasar yang stabil, maka peluang terjadinya underpricing saham akan semakin rendah. Namun, berdasarkan hasil penelitian ini, IHSG tidak berpengaruh signifikan terhadap tingkat underpricing saham. Hal ini dikarenakan banyak faktor yang mempengaruhi kondisi pasar, salah satunya dipengaruhi oleh faktor kestabilan perekonomian secara makro. Hasil dari temuan ini menunjukkan bahwa kebanyakan investor waktu membeli saham perdana tidak mempertimbangkan kondisi pasar, atau dengan kata lain kondisi pasar kemungkinan tidak dipergunakan untuk mengambil keputusan investasi di pasar modal.

Pengaruh total asset turnover, debt to equity ratio, ukuran perusahaan, nilai tukar rupiah dan IHSG terhadap underpricing

Pada tabel 6 menjelaskan bahwa secara bersama-sama variabel independen total asset turnover, debt to equity, ukuran perusahaan, nilai tukar rupiah, dan IHSG mremiliki pengaruh yang signifikan terhadap tingkat underpricing saham. Nilai signifikansi pada uji $F$ sebesar 0,000, yang menunjukkan bahwa nilai signifikansi tersebut lebih kecil dari 0,05. Berdasarkan hasil tersebut dapat disimpulkan bahwa $\mathrm{H}_{0}$ ditolak dan $\mathrm{H}_{\mathrm{a}}$ diterima, artinya variabel total asset turnover, debt to equity ratio, ukuran perusahaan, nilai tukar rupiah, dan IHSG berpengaruh secara simultan terhadap tingkat underpricing. Niilai koefisien determinasi atau adjusted $R$ square bernilai 0,179 atau sama dengan 17,9\%, yang berarti secara simultan variabel total asset turnover, debt to equity ratio, ukuran perusahaan, nilai tukar rupiah, dan IHSG berpengaruh secara simultan mampu memengaruhi tingkat underpricing saham sebesar $17.9 \%$, dan sisanya dipengaruhi oleh variabel lain di luar penelitian ini.

\section{KESIMPULAN}

Hasil penelitian menunjukkan bahwa variabel total asset turnover dan ukuran perusahaan secara parsial berpengaruh signifikan dengan arah hubungan negatif terhadap tingkat underpricing saham yang melakukan IPO di BEI Periode 2015-2019. Sementara itu, variabel debt to equity ratio (DER), dan IHSG, secara parsial berpengaruh tidak signifikan dengan arah hubungan positif terhadap terjadinya tingkat underpricing saham yang melakukan IPO di BEI Periode 2015-2019. Hanya variabel nilai tukar rupiah yang secara parsial menunjukkan pengaruh tidak signifikan dengan arah hubungan negatif terhadap terjadinya tingkat underpricing saham yang melakukan IPO di BEI Periode 2015-2019. Namun demikian, secara simultan kelima variabel tersebut berpengaruh signifikan terhadap tingkat terjadinya underpricing saham yang melakukan IPO di BEI Periode 20152019.

Secara praktis, hasil ini memberikan pemahaman bagi investor yang akan membeli atau berinvestasi saham di pasar perdana, hendaknya mempertimbangkan nilai total asset turnover dan ukuran perusahaan, karena pada penelitian ini terbukti bahwa variabel tersebut berpengaruh terhadap tingkat underpricing. Perlu pengembangan lebih lanjut untuk mendapatkan hasil yang lebih komprehensif, dengan menambah lebih banyak jumlah variabel, sampel, atau memperpanjang periode pengamatan. 


\section{DAFTAR PUSTAKA}

Aini, S. N. (2013). Faktor-faktor yang mempengaruhi underpricing saham pada perusahaan IPO di BEI periode 2007-2011. Jurnal Ilmiah Manajemen, 1(1).

Aridhonda. (2013). Pengaruh likuiditas, total asset turnover, ukuran perusahaan, dan umur perusahaan terhadap initial return pada perusahaan yang melakukan IPO di bursa efek Indonesia tahun 20082012. Skripsi. Universitas Negeri Padang.

Barus, A. C., \& Leliani, D. (2013). Analisis faktor-faktor yang mempengaruhi profitabilitas pada perusahaan manufaktur yang terdaftar di bursa efek Indonesia. Jurnal Wira Ekonomi Mikroskil, 3(2), 111-121.

Fitriani, E. (2019). Pengaruh risiko investasi, return on equity (Roe), proceeds, likuiditas, dan nilai tukar rupiah (KURS) terhadap underpricing dengan reputasi underwriter sebagai variabel moderasi pada perusahaan go public yang IPO di bursa efek. Skripsi. Fakultas Ekonomi, Universitas Muria Kudus.

Ghozali, I. (2016). Aplikasi analisis multivariate dengan program SPSS. Semarang: Badan Penerbit Universitas Diponegoro.

Gunawan, M., \& Jodin, V. (2015). Faktor-faktor yang mempengaruhi tingkat underpricing saham pada perusahaan yang melakukan initial public offering yang terdaftar di bursa efek Indonesia". Jurnal Ekonomi, 20(2), 174-19.

Hadianto, \& Tayana. (2010). Pengaruh risiko sistematik, struktur aktiva, profitabilitas, dan jenis perusahaan terhadap struktur modal emiten sektor pertambangan: Pengujian hipotesis static-trade off. Jurnal Dinamika Manajemen, 2(1), 15-39.

Haska, D. (2017). Pengaruh risiko investasi, return on equity (ROE) dan proceeds terhadap underpricing dengan reputasi underwriter sebagai variabel moderasi pada perusahaan non keuangan yang IPO di BEI periode 2010-2014. JOM Fekon, 4(1).

Imawati, \& Adnyana, I. M. (2017). Pengaruh faktor-faktor mikro dan makro ekonomi terhadap tingkat underpricing pada saat inital public offering (IPO). Oikonomia, 13(2), 72-86.

Jogiyanto. (2010). Teori portofolio dan analisis investasi. Edisi 7. Yogyakarta: BPFE.

Maulidya, P. S., \& Lautania, M. F. (2016). Pengaruh asset turnover, current ratio, debt to equity ratio, dan ukuran perusahaan terhadap terjadinya underpricing saham pada perusahaan di pasar penawaran saham perdana yang terdaftar di bursa efek Indonesia. Jurnal Ilmiah Mahasiswa Ekonomi Akuntansi (Jimeka), 1(1).

Mayasari, T., \& Yulianto, A. (2018). Pengaruh return on equity, net profit margin dan ukuran perusahaan terhadap underpricing. Jurnal Kajian Akuntansi, 2(1), 41-53.

Modigliani. F., \& Miller, M. H., (1963). Corporate income taxes and the cost of capital: A correction. American Economic Review, 53(3), 433-443.

Pahlevi, R. W. (2014). Analisis faktor-faktor yang mempengaruhi underpricing saham pada penawaran saham perdana di bursa efek Indonesia. Jurnal Siasat Bisnis, 18(2), 219-232. https://doi.org/10.20885/jsb.vol18.iss2.art8.

Rachmadhanto, D. T., \& Raharja. (2014). Analisis pengaruh faktor fundamental perusahaan dan kondisi ekonomi makro terhadap tingkat underpricing saat penawaran umum perdana (Studi empiris pada perusahaan go publik yang terdaftar di bursa efek Indonesia tahun 2008-2011). Diponegoro Journal of Accounting, 3(4), 1-12.

Renoldy, A., Lucky, E., \& Sitinjak, M. (2018). Pengaruh faktor-faktor keuangan dan perilaku herding investor terhadap underpricing pada penawaran perdana saham perusahaan yang terdaftar di BEI. 1(1), 125.

Samsul, M. (2006). Pasar modal \& manajemen portofolio. Jakarta: Erlangga

Sembiring, E. F., Rahmawati, G., \& Kusumawati, F. W. (2018). Analisis faktor yang mempengaruhi underpricing pada perusahaan yang terdaftar di bursa efek Indonesia tahun 2010-2016. Jurnal Inspirasi Bisnis dan Manajemen, 2(2), 167-176.

Sugiyono. (2017). Metode penelitian kuantitatif, kualitatif dan RED. Bandung: Alfabeta.

Sukirman, S., Wiratno, A., \& Amperaningrum, I. (2011). Pengaruh informasi asimetris umur perusahaan reputase auditor return on equity, IHSG terhadap underprecing pada perusahaan yang go public di bursa efek Indonesia. In Proceeding PESAT (Psikologi, Ekonomi, Sastra, Arsitektur ESipil). 
PENGARUH TOTAL ASSET TURNOVER, DEBT TO EQUITY RATIO (DER), UKURAN PERUSAHAAN, NILAI TUKAR RUPIAH, DAN IHSG TERHADAP TERJADINYA TINGKAT UNDERPRICING SAHAM

Wikartika, I., \& Fitriyah, Z. (2018). Pengujian trade off theory dan pecking order theory di Jakarta Islamic Index. Jurnal BISMA (Bisnis Dan Manajemen), 10(2), 90. https://doi.org/10.26740/bisma.v10n2.p90101.

Yuliana, V. (2013). Analisis pengaruh variabel keuangan dan non keuangan terhadap initial return dan return setelah IPO. Management Analysis Journal. 2(2), 1-14.

Yuniarti, D., \& Syarifudin, A. (2020). Pengaruh leverage, profitabilitas dan ukuran perusahaan terhadap underpricing pada saat initial public offering (Studi kasus pada perusahaan go public tahun 20152018). JIMMBA, 2(2), 214-227. 